\title{
GEOCHEMICAL CHARACTERISTICS OF MANTLE XENOLITHS FROM PENGHU ISLANDS, TAIWAN STRAITS, SE ASIAN MARGIN
}

\author{
Kuo-Lung Wang', Suzanne Y. O'Reilly ${ }^{1}$, William L. Griffin ${ }^{1,2}$, Sun-Lin Chung ${ }^{3}$ and \\ Wen-Shing Juang ${ }^{4}$ \\ ${ }^{I}$ GEMOC ARC National Key Centre, Department of Earth \& Planetary Sciences, Macquarie University, Sydney, Australia; \\ ${ }^{2}$ CSIRO Exploration and Mining, North Ryde, Australia \\ ${ }^{3}$ Department of Geosciences, National Taiwan University, Taipei, Taiwan R.O.C; \\ ${ }^{4}$ Department of Geology, National Museum of Natural Science, Taichung, Taiwan R.O.C.
}

\section{INTRODUCTION}

Studies of the geochemical characteristics of mantle xenoliths in continental areas have indicated that the mantle lithosphere generally undergoes a complex history of depletion and enrichment in response to multiple episodes of partial melting and metasomatism. Since the Cenozoic, the entire East Asian continental margin has undergone extension due to the late Mesozoic subduction of the PaleoPacific plate beneath Eurasia or the Indo-Eurasia collision since the early Paleogene, accompanied by widespread intraplate volcanism. The Cenozoic basaltic volcanism in Eastern China captured abundant mantle xenoliths that can shed light on the composition and evolution of the subcontinental lithospheric mantle (SCLM) beneath the region. In this study we present geochemical characteristics of mantle xenoliths from the Penghu Islands located in the Taiwan Straits, southeastern China. These data reveal the complex history of metasomatism that occurred in the SCLM, which might be related to tectonic evolution in the SE Asian margin.

\section{SAMPLE DESCRIPTION}

The xenoliths investigated in this study come from two localities in the Penghu Islands in the Taiwan Straits: Kueipi in the main island and the Tungchihsu islet (Fig. 1). The Penghu islands are made up of Miocene basaltic lavas (16 8 Ma; Chung et al., 1994) which can be divided into alkaline and tholeiitic suites. The Kueipi xenoliths were collected from alkaline lava flows with ages of 13-10 Ma (C.Y. Lee, unpubl. data). The Tungchihsu xenoliths were collected from a pyroclastic flow in the lower sequence which has an age of 11.2-13.2 Ma (Ho et al., 2000).

These xenoliths are dominantly spinel peridotites with minor spinel pyroxenites. Most peridotites have fine to coarse-grained porphyroclastic or equigranular

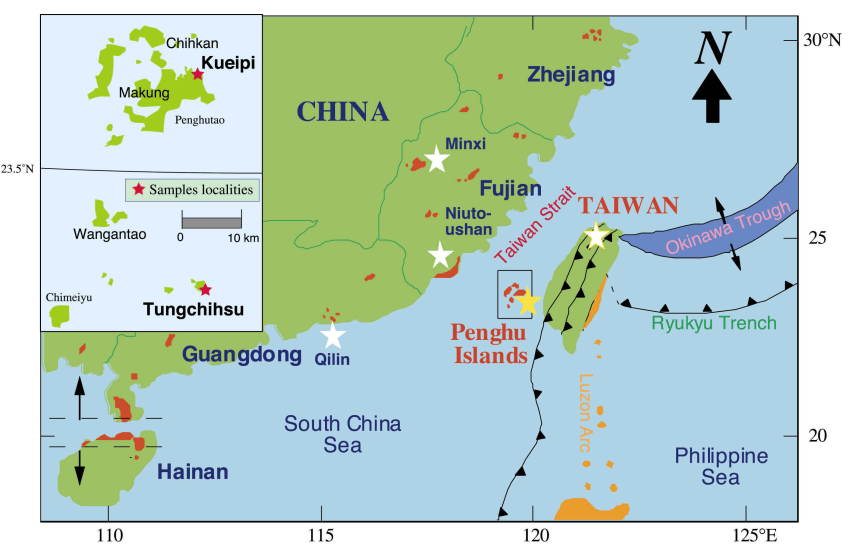

Fig. 1: A simplified tectonomagmatic map of the South China and Taiwan region. Red areas mark outcrops of late Cenozoic intraplate basalts. Stars mark localities of mantle xenoliths: the yellow one indicates xenoliths in this study. The inset shows detail sample localities in Penghu Islands.

microstructures, and some are foliated. They commonly show textural disequilibrium with clinopyroxene exsolution lamellae in orthopyroxenes, spinel exsolution in clinopyroxenes, and strained clinopyroxene grains coexisting with strain-free clinopyroxene neoblasts. These peridotites range from relatively fertile compositions, with 10-20 vol.\% clinopyroxene (cpx), to depleted compositions with $<5$ vol. \% cpx. Whereas rare Kueipi xenoliths contain amphibole and/or apatite, most Tungchihsu xenoliths contain amphibole, reflecting modal metasomatism. They also show complex episodes of fluid inclusions in orthoand clinopyroxene pophyroblasts, indicating at least two different episodes of metasomatism.

\section{GEOCHEMICAL CHARACTERISTICS}

\section{MAJOR ELEMENTS}

Major-element compositions of the minerals were analyzed using a Cameca SX50 electron microprobe at GEMOC, Macquarie University (see www.es.mq.edu.au/GEMOC for 
analytical procedures). Most peridotites have generally homogeneous mineral compositions, however, some show variation in mineral grains. Some orthopyroxenes have cores with high $\mathrm{Ca}$ contents, indicating partial equilibration of the rims to lower temperatures. Such zoning suggests some of these peridotites may represent upwelling of deeper mantle materials. From the mineral compositions, equilibration temperatures of these peridotites estimated using two-pyroxene geothermometer of Brey and Kohler (1990) range from $880^{\circ} \mathrm{C}$ to $1015^{\circ} \mathrm{C}$. The Fo contents of olivines in spinel peridotites range from 89.0 to 91.7 , but most fall between 90.0 and 91.0 ; mg\# of olivine is correlated with cr\# (0.11 0.55) in spinel. As shown in the plot of Fo\# in olivine vs modal olivine (Fig. 2), most peridotites fall between the fields of "Phanerozoic" and "Proterozoic" lherzolite range (Griffin et al., 1998) as do those from nearby Minxi, Niutoushan and Qilin peridotites (Xu et al., 2000), however, two peridotites from Tungchihsu plot in the Proterozoic range. This indicates that some of the lithospheric mantle beneath this region is moderately refractory and may be ancient. Estimate whole-rock $\mathrm{Al}_{2} \mathrm{O}_{3}$ and $\mathrm{CaO}$ of these peridotites ranges from 1.2-4.7 wt.\% and 1.5-4.6 wt. \%, respectively, which also suggests that some peridotites are relatively depleted.

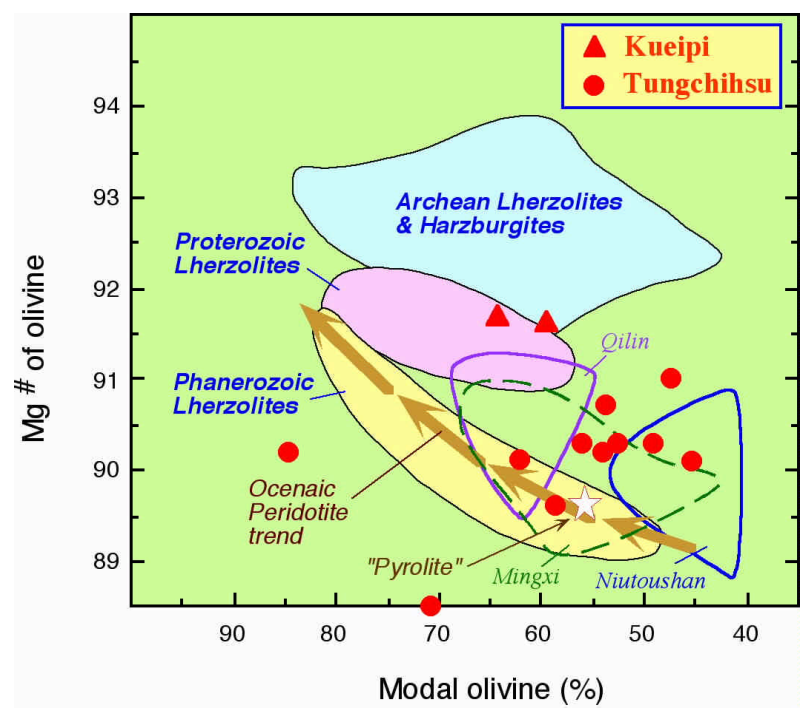

Figure 2: Plots of Mg-number versus modal olivine (\%) of peridotites with sulfides from Penghu Islands. Peridotites from nearby Minxi, Niutoushan and Qilin, inland southeastern China are also plotted for comparison (Xu et al., 2000). Oceanic trend cited from Boyd (1989). Phanerozoic, Proterozoic and Archean areas are from Griffin et al. (1998).

\section{TRACE ELEMENTS}

Trace-element compositions of the minerals were determined by laser ablation microprobe-inductively coupled plasma-mass spectrometry (LAM-ICPMS) at GEMOC, Macquarie University (see www.es.mq.edu.au/ GEMOC for analytical procedures). The mantle-normalized trace-element patterns of clinopyroxenes from peridotites show considerable variation, even between grains in the same sample and in the grain itself. They can be divided into three distinct groups as shown in Fig. 3: depleted, enriched and intermediate. The depleted pattern, showing depletion in large ion lithophile elements (LILE) and light rare earth elements (LREE) and negative $\mathrm{Sr}$ and $\mathrm{Ti}$ anomalies (Fig. 3a), is less common than other two groups. The enriched pattern, most from fertile peridotites with high modal cpx in Kueipi and all peridotites from Tungchihsu, displays enriched LILE and LREE but has negative $\mathrm{Nb}, \mathrm{Pb}$, Hf and Ti anomalies (Fig. 3a, b, d). Most of Kueipi peridotites show $\mathrm{Sr}$ depletion but few of them have a minor positive anomaly. In some peridotites with enriched patterns, different grains in cpx show variation in trace-element abundance (Fig. 3b). In Tungchihsu peridotites (Fig. 3d), all showing enriched patterns, amphibole-bearing peridotites have highest LREE contents $\left(\mathrm{La}_{\mathrm{N}}=60\right)$ with distinct negative $\mathrm{Nb}$ and $\mathrm{Ti}$ anomalies whereas amphibole-free peridotites have lower trace-element abundance similar to that of enriched Kueipi peridotites. The intermediate pattern, common in Kueipi peridotites, is marked by their similar heavy REE (HREE) abundance with dramatic variation in LILE and LREE contents (Fig. 3c). The pattern is similar to the "chromatographic" pattern due to percolating melts interacting with wall-rock in the mantle (Navon and Stolper, 1987). Notably, the pattern showing variation in LILE and LREE can be found in a single grain or separate grains in the same peridotite and may indicate recent processes. This "chromatographic" pattern is convex-downward with pronounced negative $\mathrm{Zr}$ and $\mathrm{Ti}$ anomalies (Fig. 3c).

\section{DISCUSSION}

\section{METASOMATISM: TRACE-ELEMENT FINGERPRINTS}

The depleted trace-element pattern of cpx, $(\mathrm{La} / \mathrm{Yb})_{\mathrm{N}}=0.13$ and $(\mathrm{La})_{\mathrm{N}}=0.5$ (Fig. 3a), is typical of unmetasomatised, refractory, lithospheric mantle. Alternatively, the enriched and intermediate ones might result from metasomatism. The amphibole-bearing peridotites, all showing $\mathrm{cpx}$ with enriched patterns, have evidently experienced metasomatism. Proposed metasomatic agents include $\mathrm{CO}_{2} \pm \mathrm{H}_{2} \mathrm{O}$ rich fluids and alkali-rich silicate to carbonate melts (e.g., Green and Wallace, 1988, O'Reilly and Griffin, 1988). According to experimental studies, whereas metasomatism by hydrous silicate melts may cause enrichment in incompatible elements (LILE, LREE and HFSE; Green, 1973), carbonate-rich melts are capable of transporting large amount of LILE and LREE but limited HFSE (Green and 


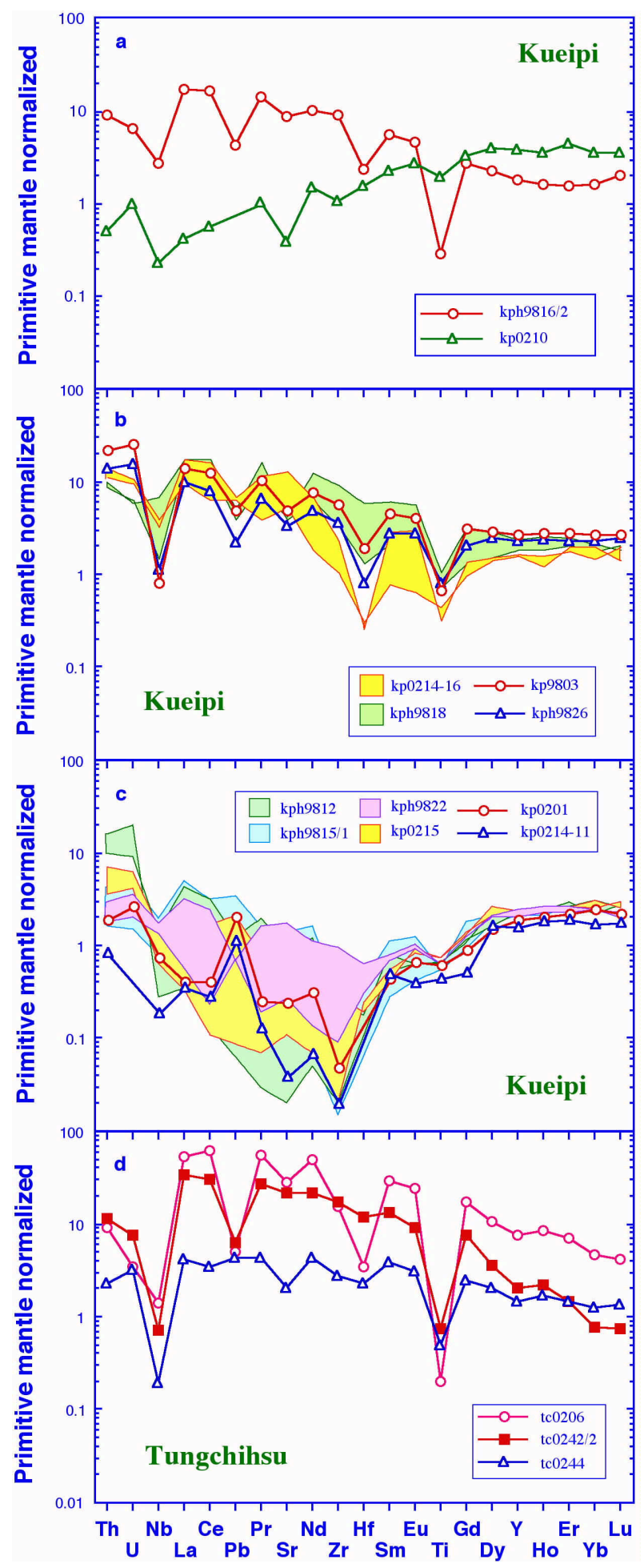

Figure 3: Mantle-normalized trace-element pattern of cpx in Penghu peridotites. (a) Cpx with depleted and enriched patterns. (b) Cpx with enriched patterns showing intra-sample variation. (c) Cpx with intermediate patterns showing variation in LILE and LREE whereas their HREE abundance remains relatively constant. All cpx in (a), (b) and (c) are from Kueipi peridotites. (d) Cpx from Tungchihsu peridotites all show enriched patterns. Normalizing values are from Sun and McDonough (1989).
Wallace, 1988). The enriched patterns of $\mathrm{cpx}$ showing distinctly negative $\mathrm{Nb}, \mathrm{Pb}, \mathrm{Sr}, \mathrm{Hf}$ and $\mathrm{Ti}$ anomalies (Fig. 3a, $3 b)$ suggest that these cpx were affected by carbonatitic metasomatism. Coltorti et al. (1999 and references therein) reported that products of a carbonatite melt show enrichment in REE and depletion in $\mathrm{Ti}$ which can use $(\mathrm{La} / \mathrm{Yb})_{\mathrm{N}}$ vs Ti/Eu as an indicator. As shown in Fig. 4, cpx with enriched patterns, two from Tungchihsu (Fig. 3d), one from Kueipi (Fig. 3a; both in red in Fig. 4) and parts of grains in peridotites from Kueipi (Fig. 3c; in pale blue in Fig. 4), plot well within the field for carbonatite metasomatism. Some enriched cpx plots outside the field, indicating metasomatism by both carbonatitic and silicate fluids.

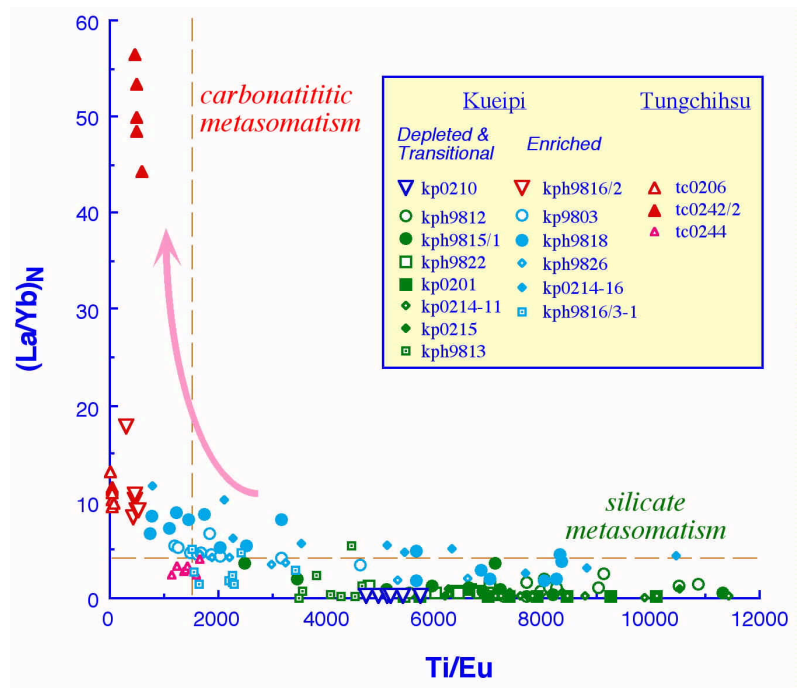

Figure 4: $(\mathrm{La} / \mathrm{Yb})_{\mathrm{N}}$ vs $\mathrm{Ti} / \mathrm{Eu}$ ratios of clinopyroxenes from Penghu Islands peridotites. Modified from Coltorti et al. (1999).

The intermediate "chromatographic" pattern of cpx may provide signatures from different type and/or episode of metasomatism. In comparison to cpx with the depleted pattern, their HREE contents are lower indicating that prior to re-enrichment by the metasomatism they have experienced partial melting events (Fig. 3c). It is also suggested by their more refractory major-element characteristics. Generally they do not show obvious negative $\mathrm{Nb}, \mathrm{Sr}, \mathrm{Hf}$ and $\mathrm{Ti}$ anomaly as that of enriched ones, but have a distinct negative $\mathrm{Zr}$ anomaly and some positive $\mathrm{Pb}$ and $\mathrm{Sr}$ spikes (Fig. 3c). Combining with their $(\mathrm{La} / \mathrm{Yb})_{\mathrm{N}}$ vs Ti/Eu relationship (Fig. 4), they are most likely products of silicate metasomatism. The most remarkable feature is their "chromatographic" pattern in one single grain or one single sample. Previous studies regarding the "chromatographic" pattern show geochemical variation with spatial (depth) distribution. Here we find the "chromatographic" variation on a millimeter scale. The cpx in these peridotites also shows higher trace-element abundance in the rim than that in the core. Thus, we interpret that the "chromatographic" phenomenon most likely indicates chemical 
disequilibrium with time as the metasomatic agent acted on the rim of grain then diffuse into the core from fluid or melt percolated in veins and/or porous systems near the grain. This metasomatism occurred recently that the grains were not geochemically equilibrated. Thus, another younger episode of metasomatism than that affected peridotites with enriched cpx has been revealed.

\section{OLD LITHOSPERE RELICS BENEATH TAIWAN STRAITS REGION?}

Xu et al. (2000) have pointed out that although most mantle xenoliths from South China Block are relatively fertile, suggesting that the old Proterozoic lithosphere beneath it has been replaced by younger mantle during late the Mesozoic to Cenozoic, some strongly depleted xenoliths indicate that older lithospheric mantle material is embedded in the Cenozoic lithosphere beneath the region. Similar observation has been reported in eastern China region (Zheng et al., 2001). Major-element compositions of peridotites from Penghu Islands suggest that some old and refractory parts of lithosphere do exist beneath the region. The age of these parts of old lithosphere may be Proterozoic (Fig. 2). New evidence comes from our latest results on in situ Re-Os isotope composition of sulfides from these peridotites (Wang, K-L, unpublished data), which shows some ages for the SCLM are as old as Paleo-Proterozoic.

\section{CONCLUSION}

Mantle xenoliths in Miocene intraplate alkali basalts in the Penghu Islands, Taiwan Straits provide evidence for different mantle domains in composition and age beneath the region. Petrographic and geothermal evidence suggest some of these peridotites may have originated from upwelling of deeper mantle materials. The major-element data for xenoliths suggests that some of the lithospheric mantle beneath this region is quite refractory, and may be Proterozoic based on new Re-Os sulfide isotope data. Traceelement patterns of clinopyroxene in these peridotites can be divided into three types: depleted, enriched and intermediate. At least two episodes of metasomatism resulted from different metasomatic agents can be recognized in the SCLM. All geochemical characteristics reveal that ancient, refractory Proterozoic lithospheric mantle is embedded in the younger, fertile lithosphere beneath Taiwan Straits region. The ancient Proterozoic mantle domain has survived, but may have been subjected to metasomatic re-enrichment during the Miocene extension and thinning in this region.

\section{REFERENCES}

Boyd, F.R., 1989. Compositional distinction between oceanic and cratonic lithosphere: Earth Planet. Sci. Lett. 96, 15-26.

Brey, G.P. and Kohler, T., 1990. Geothermobarometry in fourphase lherzolites, II. New Thermobarometers: J. Petrol. 31, 1353-1378.

Chung, S.L., Sun, S.-s., Tu, K., Chen, C.-H. and Lee, C.Y., 1994. Late Cenozoic basaltic volcanism around the Taiwan Strait SE China: Product of lithosphere-asthenosphere interaction during continental extension: Chem. Geol. 112, 1-20.

Coltorti, M., Bonadiman, C., Hinton, R.W., Siena, F., and Upton, B.G.J., 1999. Carbonatite metasomatism of the oceanic upper mantle: evidence from xenoliths of Grande Comore, Indian Ocean: J. Petrol. 4., 133-165.

Green, D.H., 1973. Experimental melting studies on a model upper mantle composition as high pressure under water-saturated and water-undersaturated conditions: Earth Planet. Sci. Lett. 19, 37-55.

Green, D.H. and Wallace, M.E., 1988. Mantle metasomatism by ephemeral carbonatite melts: Nature 336, 459-462.

Griffin, W.L., Zhang, A., O’Reilly, S.Y. and Ryan, C.G., 1998. Secular variation in the composition of subcontinental lithospheric mantle: geophysical and geodynamic implications. In: Braun, J. et al. (Eds.), Structure and Evolution of the Australian Continent: American Geophysical Union Geodynamic Series, 26, pp. 1-25.

Ho, K.-S., Chen, J.-C., Smith, A.D. and Juang, W.-S., 2000. Petrogenesis of two groups of pyroxenites from Tungchihsu, Penghu Islands, Taiwan Straits: implication for mantle metasomatism beneath SE China: Chem. Geol. 167, 355-372.

Navon O. and Stolper, E., 1987. Geochemical consequences of melt percolation: the upper mantle as a chromatographic column: J. Geol. 95, 285-307.

O'Reilly, S.Y. and Griffin, W.L., 1988. Mantle metasomatism beneath Victoria, Australia I: metasomatic processes in $\mathrm{Cr}-$ diopside lherzolites: Geochim. Cosmochim. Acta 52, 433447.

Sun, S.-s., and McDonough, W.F., 1989. Chemical and isotopic systematics of oceanic basalts: Implications for mantle composition and processes. In: Saunders, A. D. and Norry, M. J., (Eds.), Magmatism in the ocean basins. Geol. Soc. London Special Public. 42, pp. 313-345.

Xu, X., O'Reilly, S.Y., Griffin, W.L. and Zhou, X., 2000. Genesis of young lithospheric mantle in southeastern China: an LAM-ICPMS trace element study: J. Petrol. 41, 111-148.

Zheng, J.P., O’Reilly, S.Y., Griffin, W.L., Lu, F., Zhang, M. and Pearson, N.J., 2001, Relict refractory mantle beneath the eastern North China block: significance for lithospheric evolution: Lithos, 57, 43-66.

Contact: K-L Wang, GEMOC, Department of Earth \& Planetary Sciences, Macquarie University, NSW 2109, Australia, E-mail: kwang@els.mq.edu.au 